\title{
EVELOPMENT OF EARLY WARNING SYSTEM FOR SEDIMENT DEPOSITION AND PROTECTION ZONES OF RIVER INTAKES
}

Donia, Noha, S. $^{(1)}$; Shafek, N. M. ${ }^{(2)}$ and EI Sersawy, Heba, M. A. ${ }^{(2)}$

1) Institute of Environmental Studies and Research Ain Shams University

2) Nile Research Institute, National Water Research Center Cairo, Egypt.

\begin{abstract}
Major environmental problems which faced most of river intakes are successive sedimentation in front of intakes and water drawn from river intakes is inherently capability to contamination, these problems causes reducing the amount of the drawing water and decrease the station efficiency. Sedimentation problems and contamination are relatively common in Egypt, especially in the case of drinking water treatment plants intakes on River Nile. The problem of sedimentation at water intakes can largely be minimized by remove of sediment from the intakes to ensure continuous water supply from these intakes and to protect intakes from contamination.

The objectives of this study, to develop early warning system to predict the annual rate of sedimentation deposition and delineation of river Intake Protection Zones (IPZs). To achieve these objectives, the hydrodynamic delft (3d) model used for simulation and prediction of river flow, sediment deposition and particle tracing to define area of Intake Protection Zones (IPZs). The model was calibrated and verified using field measured data for Abu Teg (Assuit) water station which faced the major problem of sedimentation.

The results showed the annual rate of deposition sediment on front of Abu Teg (Assuit) water intake station is $(0.3 \mathrm{~m})$ per year. Intake Protection Zones (IPZs) of Abu Teg (Assuit) water intake station was defined under applying of two scenarios, for max flow was extended about (4.60) km and for min was extended flow (3.3) km upstream the intake. Vulnerability score was calculated and concluded that Abu Teg (Assuit) water intake represents high capability to contaminants .
\end{abstract}


This study concluded that the use of early warning system is effective tool to improve efficiency and ensures a healthy supply of river intakes.

Key words: hydrodynamic delft (3d) model, Intake Protection Zones, Sedimentation, River Nille, Travel time.

\section{INTRODUCTION}

The extraction of water rivers is one of the most ancient human activities in the field of land irrigation, electrical power generation, water-treatment facilities and river navigation systems. The construction of intake structures on river is intended to divert a certain amount of water from the river for several of utilizes (Dereja, 2003; Erbisti, 2005).

The development of intake structure consists of various methods and techniques. In particular, the intake structure should be designed to minimize the quantity of sediment that enters the intake structure. This is important to preserve suitable flow characteristics within pump intakes, prevent clogging and fouling of traveling screens, and eliminate the need for regular maintenance dredging (Nakato and Ogden, 1998).

Major environmental problems which most of lateral intakes are faced excess and successive sedimentation at river intakes on river causes a disturbance in water supply and affects passively on pumps operation which in turn leads to high indirect cost concerning operation and maintenance. Intake is inherently vulnerable to contamination this process causes many problems such as closed the water intake where potential contaminants could pose a significant risk or threat to river intake (Pirestani, et al., 2011). 
In this study it was developed early warning modeling system using the hydrodynamic delft (3D) model. The model was used to predict the annual rate of sedimentation and defines Intake Protection Zones (IPZs),(is the area around a surface water intake that is defined to protect the source water. It is the vulnerable area where potential contaminants could pose a significant risk or threat to the source water).

\section{The main objectives of this study are:}

a. Development of early warning modeling for intake water station (surface water flow conditions and potential sources of contamination).

b. Appling hydrodynamic model of river intake for simulation and prediction of river flow, sediment transport (hydrodynamic) and particle tracing.

c. Creating a base flow map for hydrological, hydraulically and morphological changes at river intakes.

d. Estimate Intake Protection Zones (IPZs) and calculate vulnerability score of water station.

\section{STUDY AREA}

The study area is located on the waterfront of Abu Teg (Assuit-Egypt) city (west bank of the Nile river) ), between ( $\mathrm{km} \mathrm{409)}$ and ( $\mathrm{km} \mathrm{405)} \mathrm{from} \mathrm{El}$ Roda gauge station south of Cairo with the total length of 4.00 kilometer and the watercourse width between 890.00 to $540.00 \mathrm{~m}$ as shown in figure (1). Abu Teg (Assuit) water intake located at km 407.960 (from downstream ElRoda gauge station). The intake of Abu Teg located in the west bank of Nile and the water intake pipe extend from west bank about $303 \mathrm{~m}$ in water source and it is near the water treatment. 
J. Environ. Sci.

Institute of Environmental Studies and Research - Ain Shams University

\section{METHODOLGY}

The methodology was developed to meet the above goals and consisted of the following components:

a. Collection of detailed physical, hydrological and hydraulically field data needed by the subsequent analysis components.

b. Appling hydrodynamic delft (3D) model using field data, boundary condition and solve momentum, continuity and sediment transport equation.

c. Development of the hydrodynamic delft (3D) model of the study reach to prediction of river flow, velocity, sediment transport, and bed level (hydrodynamic).

d. Estimate annual deposition rate at intake, area of Intake Protection zones (IPZs) and Vulnerability score. 


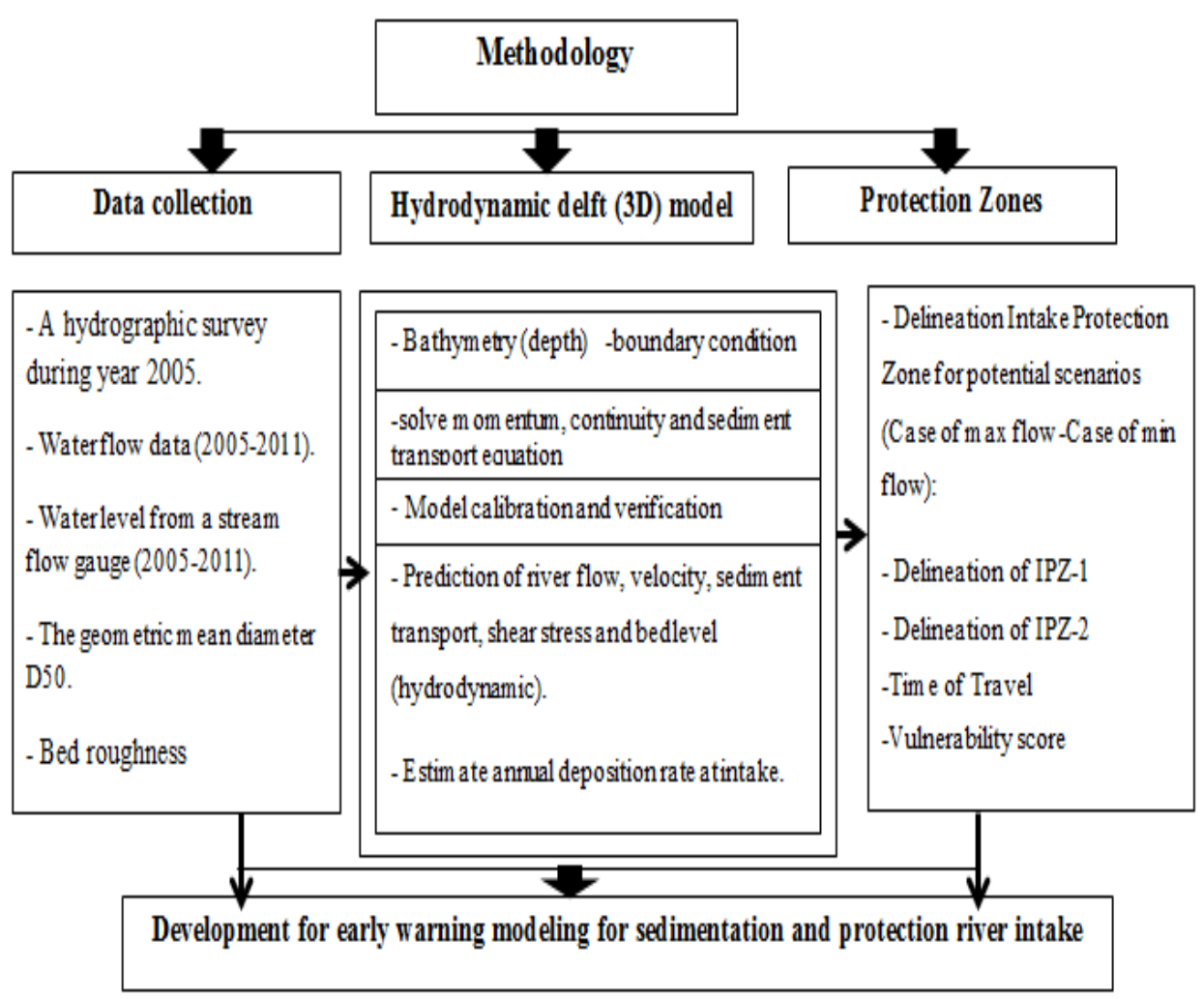

\section{Flow chart of Methodology}

\section{Data Collection:}

Hydrographic (bathymetric), hydrologic and hydraulic, data were collected as input for model.

1 Geometric Data: A hydrographic survey of the study area was carried out by the Nile Research Institute (NRI) of the National Water Research Center (NWRC). The survey was carried out along the study area, between the two banks of the river; by surveying cross sections spaced at $50 \mathrm{~m}$ intervals cover a distance of $4 \mathrm{~km}$. The vertical distributions of the velocity are determined 
for 2 cross sections. Three verticals at least are measured for each cross section. In each vertical five locations are measured, at $0.5 \mathrm{~m}$ downward the water level, $25 \%, 50 \%, 75 \%$ of the total water depth. Bed material samples are obtained using a grab samples from 2 cross sections. Three samples are taken from each cross section as shown in figure (2).

\section{Hydrologic Data}

a) The water levels were recorded gauging stations along Reach three (which begin at downstream Nag Hammadi Barrage km- 359.48 from OAD and upstream Assuit Barrage at km- 544.780 from OAD Gauge Station) during the period from 2005 to 2011 as shown in figure (3).

b) Monthly discharges downstream Nag Hammadi Barrage was collected during the period from 2005 to 2011. As shown in figure (4) the frequency of the discharge during period.

\section{NUMERICAL MODEL:}

Delft3D is the hydrodynamic module of Delft3D, which is Delft Hydraulics' fully integrated program for the modeling of water flows, waves, water quality, particle tracking, ecology, sediment and chemical transports and morphology. The primary purpose of the computational model Delft3D is to solve various one-, two- and three-dimensional, time-dependent, non-linear differential equations related to hydrostatic and non-hydrostatic free-surface flow problems on a structured orthogonal grid to cover problems with complicated geometry. The equations are formulated in orthogonal curvilinear co-ordinates on a plane or in spherical co-ordinates on the globe in version discussed here sediment transport and morphological updating is fully 
integrated within the flow module. The ability of a model to reproduce and predict measured values depends on the amount and quality of topographic and hydraulic data collected such as velocity distributions, water-surface elevation, flow rates, and bed roughness. This special feature offers a number of standard sediment transport formulations for non-cohesive sediment. Additionally, it can be used for any suitable sediment transport formula and call it from Delft3D-FLOW. Now, it is a general description of the sediment transport formulae included by default.

The Meyer-Peter-Muller sediment transport relation is slightly more advanced than the Engelund- Hansen formula, as it includes a critical shear stress for transport. It reads:

$\mathrm{S}=8 \alpha D_{50} \sqrt{\Delta g D_{50}}\left(\mu \theta-\xi \theta_{c r}\right)$

Where :

$\alpha \quad$ calibration coefficient (o (1))

$\Delta$ The relative density $\left(\rho_{\mathrm{s}}-\rho_{\mathrm{w}}\right) / \rho_{\mathrm{w}}$

$\mu \quad$ ripple factor or efficiency factor

$\theta_{\text {cr }}$ critical mobility parameter

$\xi \quad$ hiding and exposure factor for the sediment fraction considered and the shields mobility parameter $\theta$ given by

$$
\theta=\left(\frac{q}{c}\right)^{2} \frac{1}{\Delta D_{50}}
$$


In which $\mathrm{q}$ is the magnitude of the flow velocity $[\mathrm{m} / \mathrm{s}]$. The ripple factor $\mu$ reads:

$$
\mu=\min \left(\left(\frac{\mathrm{c}}{c_{\mathrm{g}, 90}}\right)^{1.5}, 1.5\right)
$$

Where $c_{g}, 90$ is the chezy coefficient related to grains, given by:

$$
c_{g, 90}=18^{10} \log \left(\frac{12(d+\varepsilon)}{D_{50}}\right)
$$

1 Grid generation: Delft 3D Model automatically generated a grid network from the map module and then interpolated the bathymetric data into the mesh. The built-in interpolate command in the grid creator module of "RGF grid" in Delft 3D was used to assign a depth for each individual node using the surveyed bed elevation in terms of (XYZ) data points.

The grid covered an area of $50 \mathrm{Km}^{2}$, with a distance of $4 \mathrm{~km}$ along shoreline. A fine grid $(11 \mathrm{~m} * 8 \mathrm{~m})$ used in the model is presented in Figure (5).

2 Initial and boundary condition: The initial boundary condition is defined as the initial water levels as well as' the bed elevation in terms of xyz data points. The initial water levels were used to simulate the flow characteristics. The boundary conditions consist of two conditions, inflow and outflow. The inflow boundary was defined as the inflow discharge to the study area which is defined as the discharge downstream Nag Hammadi Barrage. The outflow boundary condition was used as water level at the end of the study reach.

3 Calibration and Verification of the Model: Several model runs are made to achieve the best agreement between measured and resulted values from the model. This was carried out by adjusting roughness coefficients at various locations along the modeled study area till the best results are achieved. The 
simulated runs were performed to predict the effect of different releases covering most of the year on velocity distribution and bed level at the study area. The simulation carried out using the field observation water level of 51 $\mathrm{m}$ and discharge $2000 \mathrm{~m}^{3} / \mathrm{s}$ for calibration, verification runs between min. water level of $49.2 \mathrm{~m}$ and maximum water level of $51.78 \mathrm{~m}$.

Figure (6) indicates comparison of the field velocities and obtained velocity profiles at the cross sections (1) and (7). This figure shows the simulated velocity ranges between 0.1 to $.78 \mathrm{~m} / \mathrm{sec}$. From this figure it can be concluded that the velocity magnitude in the east side is higher than the velocity magnitude in west side. Figure (7) indicates comparison of the field bed level and obtained bed level profiles at the cross sections (1) and (7). These figures (6) and (7) indicate good agreement between the measured and simulated for the sections.

4 Prediction of morphological changes: The model was applied to predict the changes of the bed elevation within the study area due to the sediment transport in front of the water intake. The model used the hydrograph of the water levels and inflow discharges inside study area from year 2005 to year 2020.

Figure (8): indicate that there is a major change in the bed level in front of intake (deposition up to $3.5 \mathrm{~m}$ ) from the initial bed level contour of study area during 2005 to predicted bed level contour of study area during 2020 as shown. It's presented that the change in the bed level is about $0.3 \mathrm{~m}$ per year in front of intake. 
Figure (9): indicate that the results of model simulation for the bed level where the bed elevation varies from $47.0 \mathrm{~m}$ to $51.0 \mathrm{~m}$. it's presented a concentration of Sedimentation at the intake.

Figure (10): indicate that prediction of the changes in bed level contour. The obtained contouring map indicated the locations of sedimentation on front of the intake and erosion in the other side during period 2005to 2020.

\section{DELINEATION OF ABU TEG WATER INTAKE PROTECTION ZONES:}

The delineation methods for Intake Protection Zones (IPZs): is the area around a surface water intake that is defined to protect the source water for drinking water system. It is the vulnerable area where potential contaminants could pose a significant risk or threat to the source water.

1 Delineation of IPZ-1: The IPZ-1 is the area immediately around the water intake Abu Teg this zone is considered the most vulnerable due to its proximity to the Abu Teg water intake. The delineation of IPZ-1 is as a semicircle for $400 \mathrm{~m}$ upstream, $10 \mathrm{~m}$ along and $200 \mathrm{~m}$ upstream of intake [Rule 61-1; MOE, 2009a].

2 Delineation of IPZ-2: The IPZ-2 acts as a secondary protective zone around the IPZ-1. In the event of a spill, the treatment facility will have minimal time to respond. Contaminants released in this zone have a high chance of reaching the intake quickly and will have limited time to be diluted prior to reach the intake (MOE, 2009a), where the time that is sufficient to allow the operator to respond to an adverse condition in the quality of the 
surface water is less than two hours. To determine time travel takes into consideration the following:

- The hydrological and hydrogeological conditions of river (river velocitiesdischarge).

According to The hydrodynamic delft (3D) model using Particle tracking to define and estimate the IPZ-2 area. It calculates about (4.60) $\mathrm{km}$ from intake in case of max flow condition as shown in figure (11) and (3.5) $\mathrm{km}$ in case of min flow condition as shown in figure (12).

Tables (1): IPZ-1 and IPZ-2 for Abu Teg (Assuit) water intake

\begin{tabular}{|c|c|c|}
\hline & $\begin{array}{l}\text { case of max flow } \\
\left(2650 \mathrm{~m}^{3} / \mathrm{s}\right)\end{array}$ & $\begin{array}{c}\text { case of min flow } \\
\left(640 \mathrm{~m}^{3} / \mathrm{s}\right)\end{array}$ \\
\hline IPZ-1 & \multicolumn{2}{|c|}{$\begin{array}{l}\text { as a semi-circle for } 400 \mathrm{~m} \text { upstream , } 10 \mathrm{~m} \text { along and } 200 \mathrm{~m} \\
\text { upstream of intake }\end{array}$} \\
\hline IPZ -2 & (4.60) km upstream & (3.5) $\mathrm{km}$ upstream \\
\hline
\end{tabular}

3 Vulnerability Score (V): Early warning system used to calculate the vulnerability score $(\mathbf{V})$ for indicates contamination:

$$
\mathbf{V}=\mathbf{B} * \mathbf{C}
$$

where: $\mathbf{B}$ is Area vulnerability factor

C is source vulnerability factor

Area vulnerability factor (B): The area vulnerability factor differs between IPZ-1 and IPZ-2 in that the closer the zone to the intake the vulnerability analysis of IPZ-1, IPZ-2 for water intake Abu Teg (Assuit) includes consideration for both the area and the source as described in the Technical Rules. An IPZ-1 is always assigned a score of 10 (Technical Rule 88), while the area vulnerability factor for IPZ -2 is assigned by a value ranging (7-9) using professional judgment (Technical Rule 89). Area vulnerability factors 
were assigned by examining Hydrological and hydrogeological conditions in the area that contribute water to the area through transport pathways.

Source Vulnerability $\operatorname{Factor}(\mathbf{C})$ : The source vulnerability factor applies to the location of the intake in a particular water body. The source vulnerability factor for a Type C intake can range (0.9-1). (Technical Rule 95).

Table(2): The vulnerability scores

\begin{tabular}{|c|c|c|c|c|c|}
\hline \multirow{2}{*}{ Type intake } & \multicolumn{2}{|c|}{$\begin{array}{c}\text { Area vulnerability factor } \\
(\mathbf{B})\end{array}$} & \multirow{2}{*}{$\begin{array}{c}\text { source } \\
\text { vulnerability } \\
\text { factor (C) }\end{array}$} & \multicolumn{2}{|c|}{$\begin{array}{c}\text { Vulnerability score } \\
\text { (V) }\end{array}$} \\
\cline { 2 - 3 } & IPZ-1 & IPZ-2 & IPZ-1 & IPZ-2 \\
\hline \hline Type c & 10 & 8 & 1 & 10 & 8 \\
\hline
\end{tabular}

The results showed that the vulnerability score for Abu Teg (Assuit) water intake for (IPZ-1 and IPZ-2) is high that indicated the Abu Teg (Assuit) water intake has high capability of contaminants.

\section{CONCLUSIONS AND RECOMMENDATIONS}

In this study, it was carried out to develop early warning modeling system by using the hydrodynamic delft (3D) model to predict the annual rate of deposition sediment in front of intake, delineate Intake Protection Zones (IPZs) and identifine susceptibility of Abu Teg water intake for contaminants. From the model results, It was concluded that:

- The annual rate of deposition sediment on front of Abu Teg (Assuit) water intake station is $(0.3 \mathrm{~m})$ per year.

- Delineation of IPZ-1 is as a semi-circle for $400 \mathrm{~m}$ upstream, $10 \mathrm{~m}$ along and $200 \mathrm{~m}$ upstream of intake.

- Delineation of IPZ-2 is far (4.60) km from upstream intake (at case of max flow) and 3.3 from upstream intake (at case of min flow). 
-Vulnerability score was calculated and showed that Abu Teg (Assuit) intake represents high susceptibility to contaminants.

So that, development of early warning modeling system is effective tool to improve efficiency and ensures a healthy supply of water now and in the future of river intakes.

It is recommended to start using development of early warning modeling system for all river intakes is exists and the future river intakes for increase the efficiency of intakes.

\section{FIGURES}

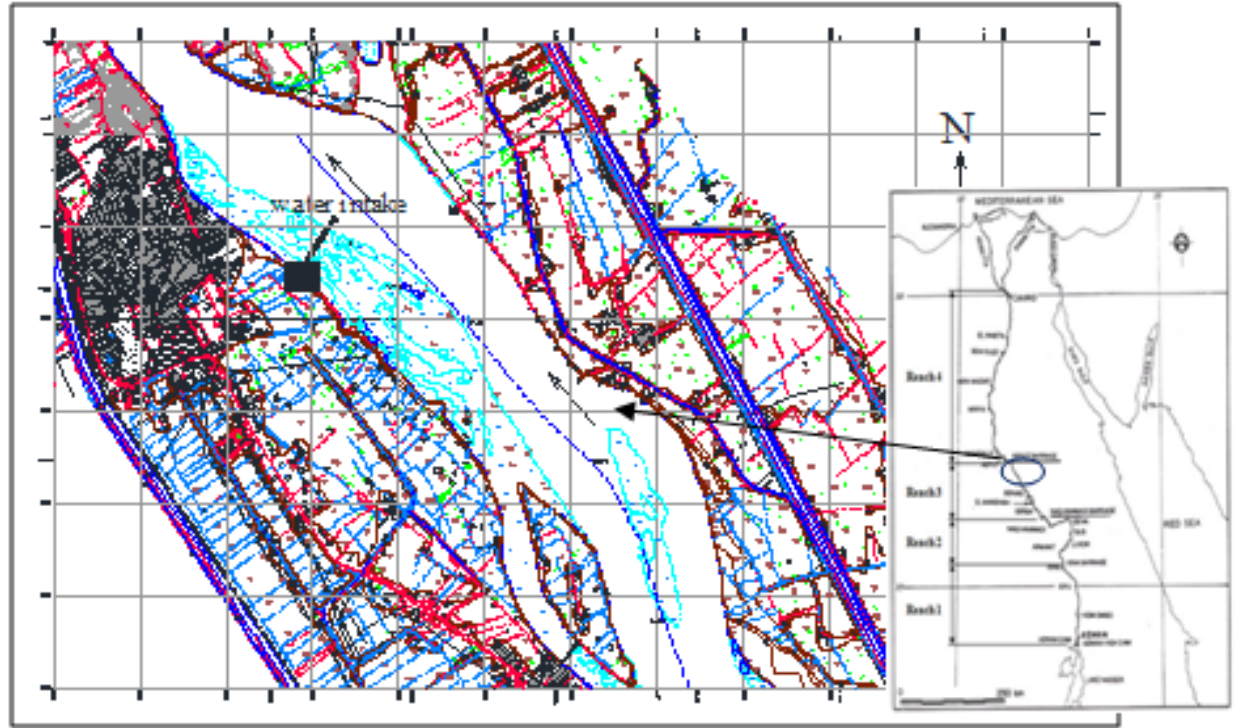

Figure(1): Abu Teg (Assuit) water Intake 


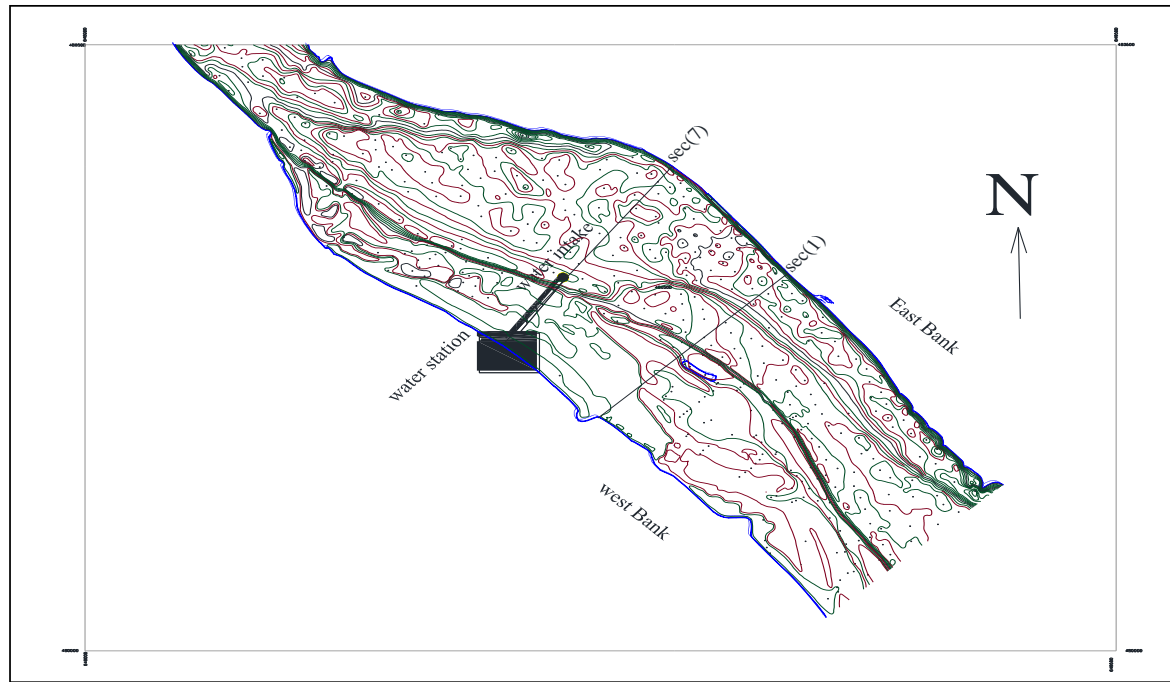

Figure(2): Contour map of the Study area and location of measured cross sections

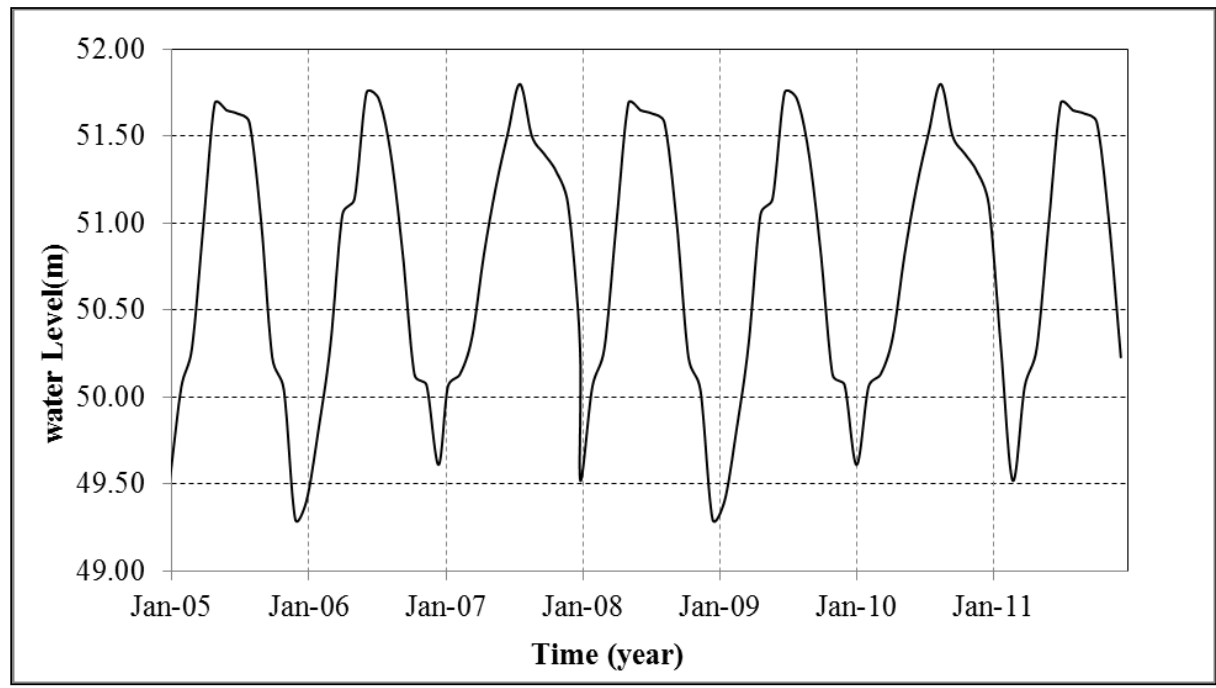

Figure(3): River Nile hydrograph at Abu Teg water intake for year (20052011) 


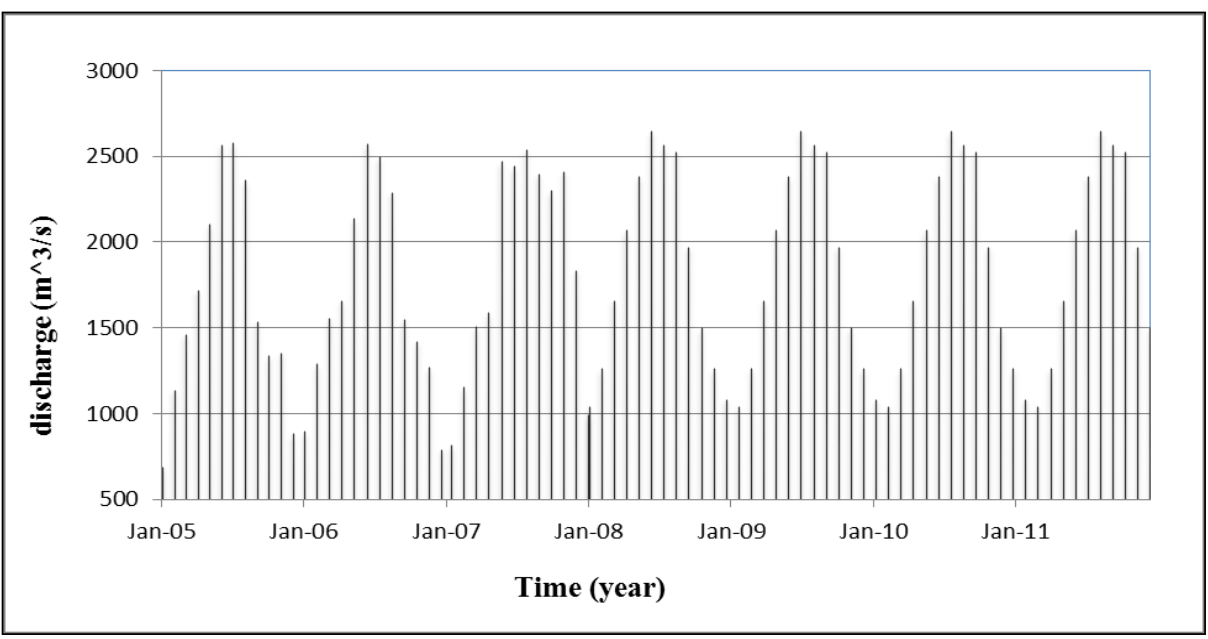

Figure (4): Water discharges downstream Nag Hammadi Barrage for year (2005-2011)

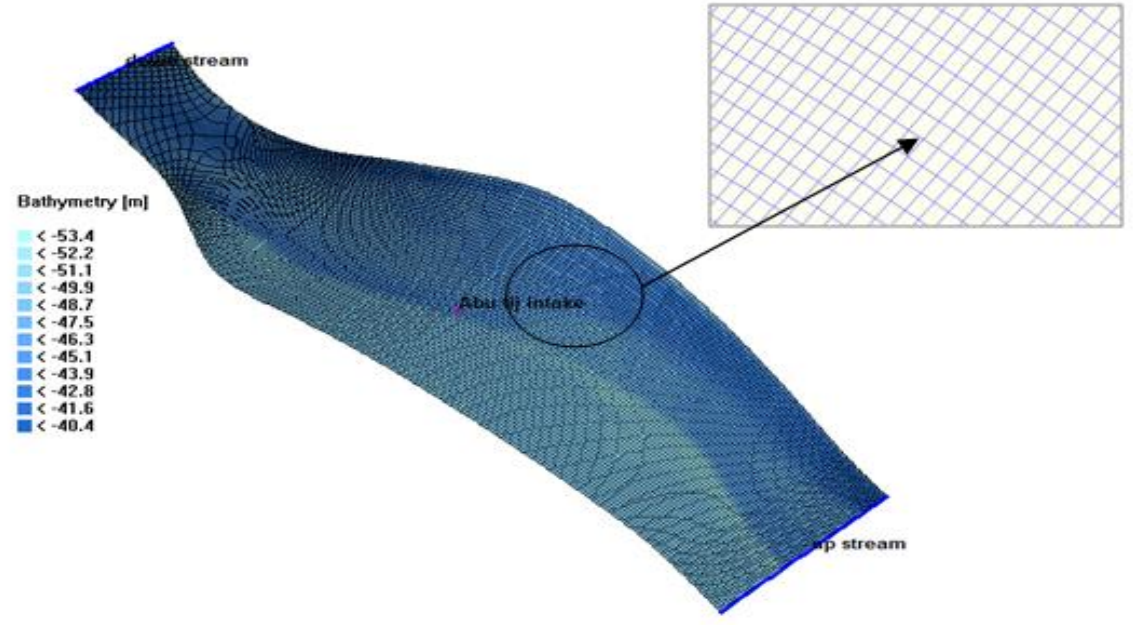

Figure(5): The grid of the model

Vol. 36, No.1, Dec. 2016 
J. Environ. Sci.

Institute of Environmental Studies and Research - Ain Shams University
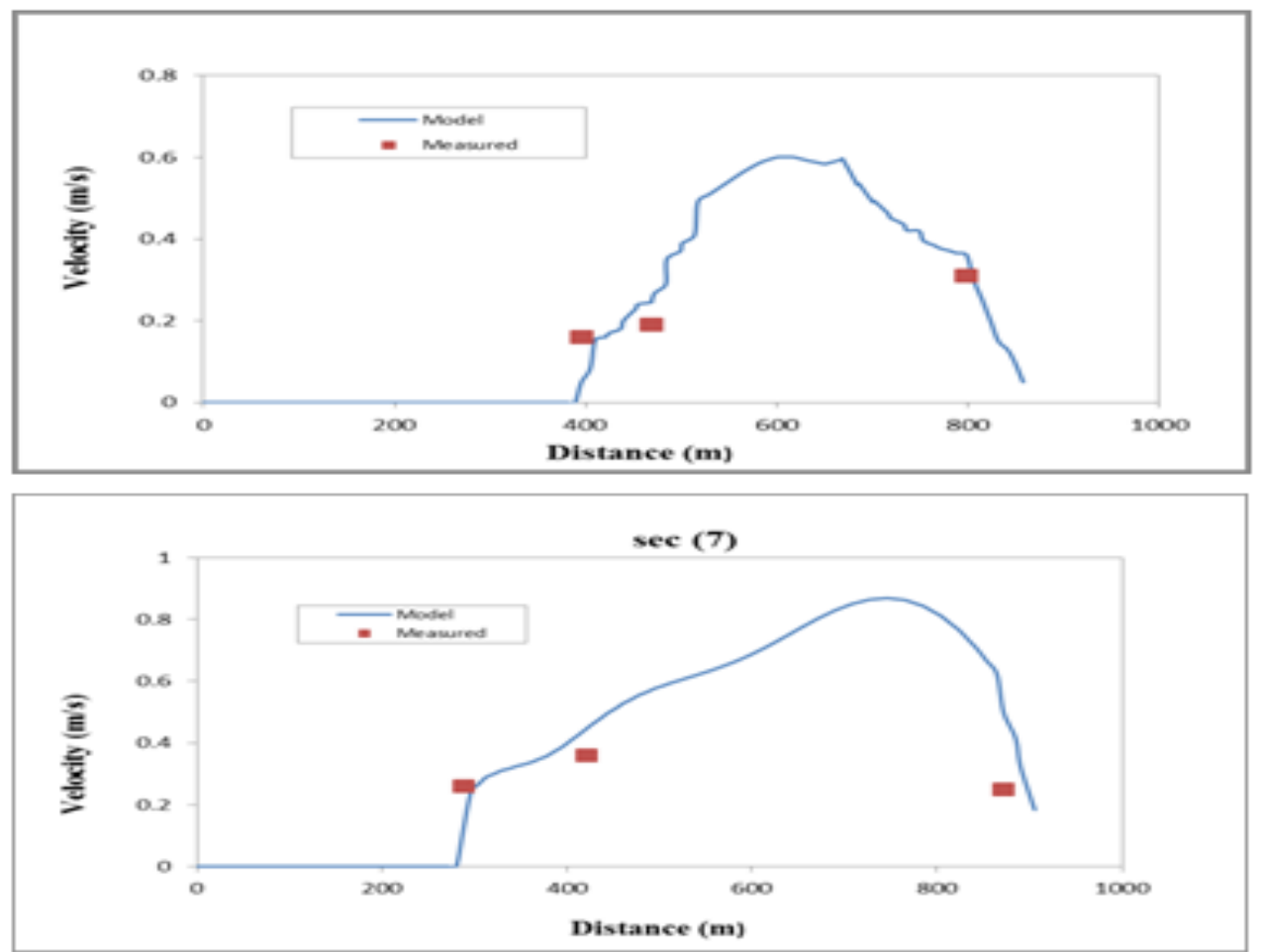

Figure(6): Comparison between measured and model velocities at Cross Section (1 and 7) 

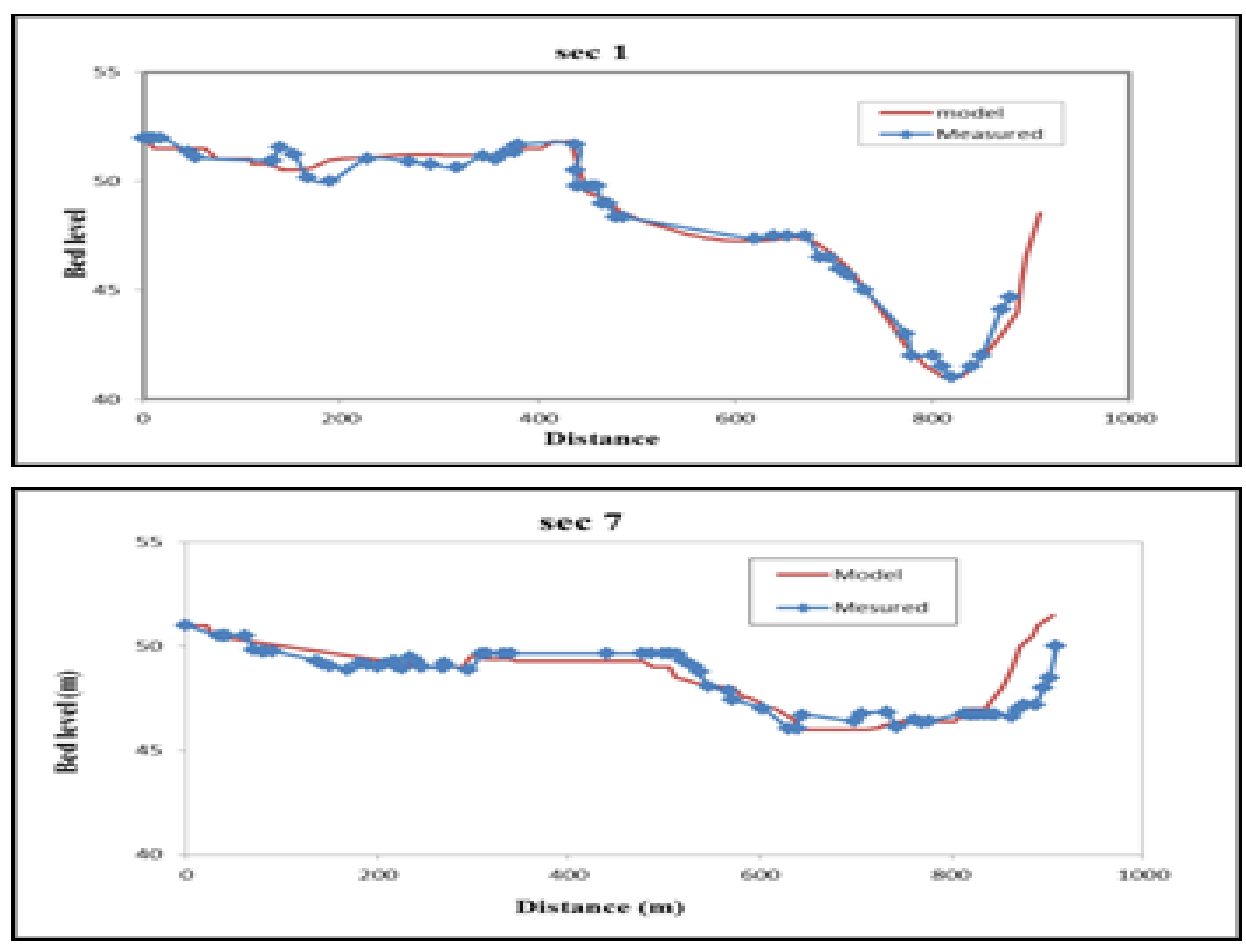

Figure(7): Comparison between measured and model bed level at cross section (1 and 7)

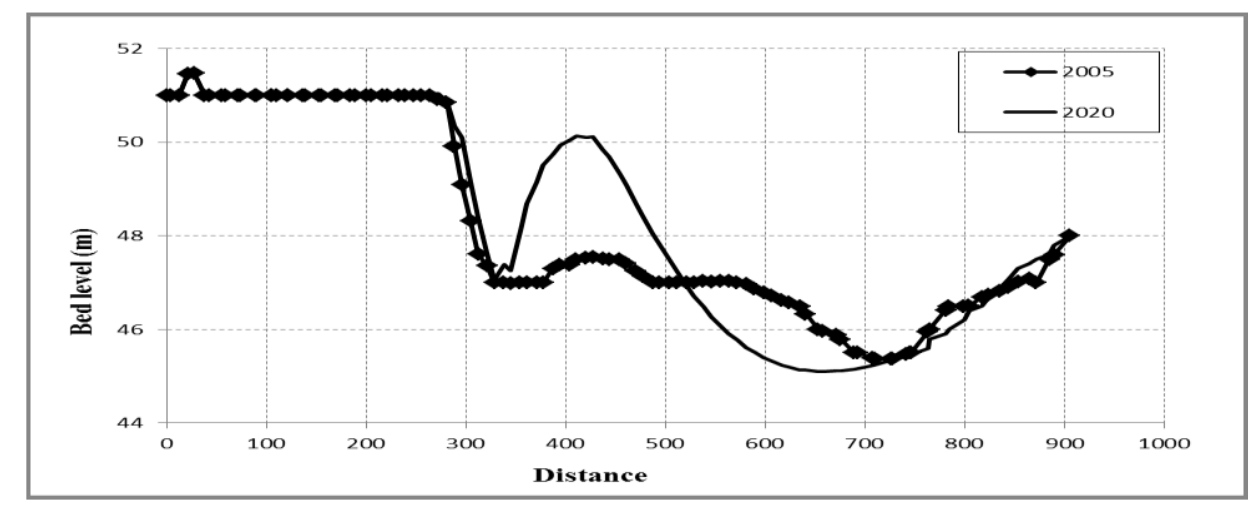

Figure(8): Comparison between actual (2005) and predicted (2020) cross section 
J. Environ. Sci.

Institute of Environmental Studies and Research - Ain Shams University

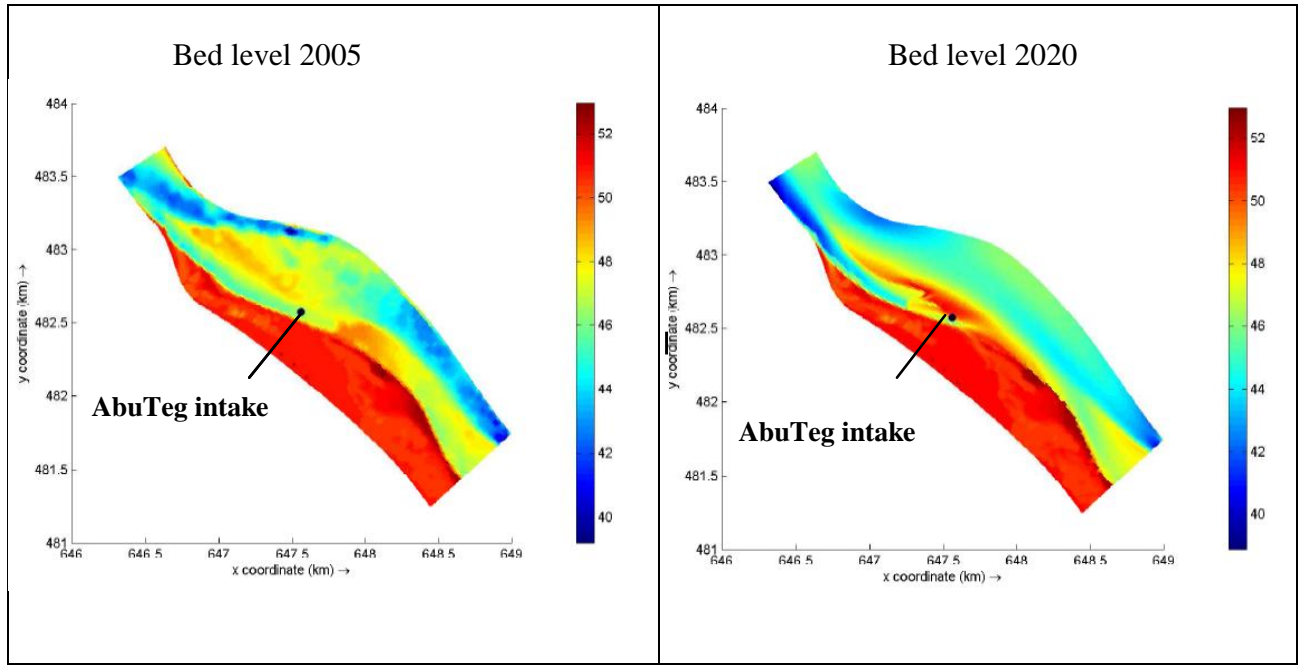

Figure (9) Morphological bed change from year (2005) to (2020)

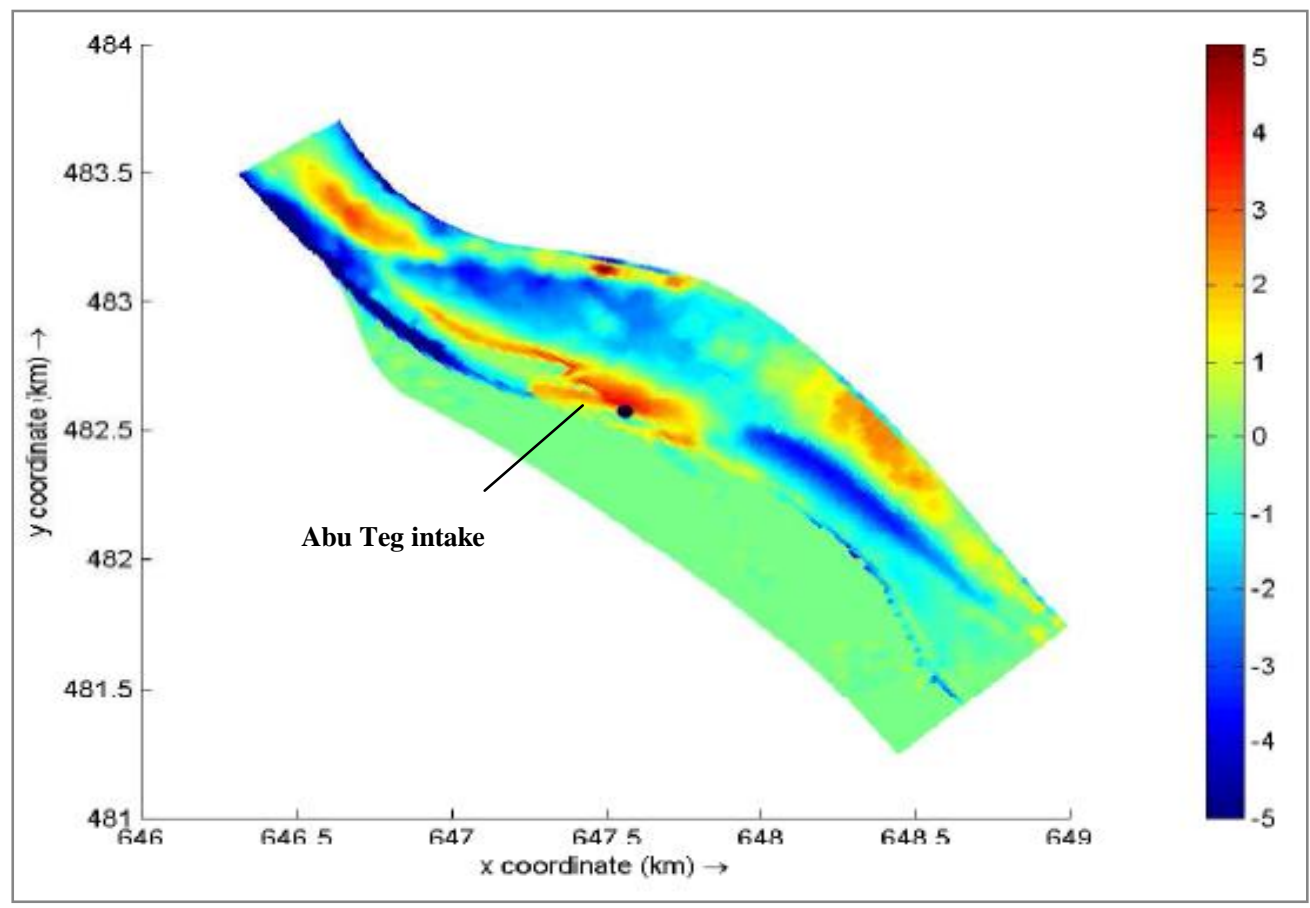

Figure(10): Bed level change occurred during (2005-2020) 


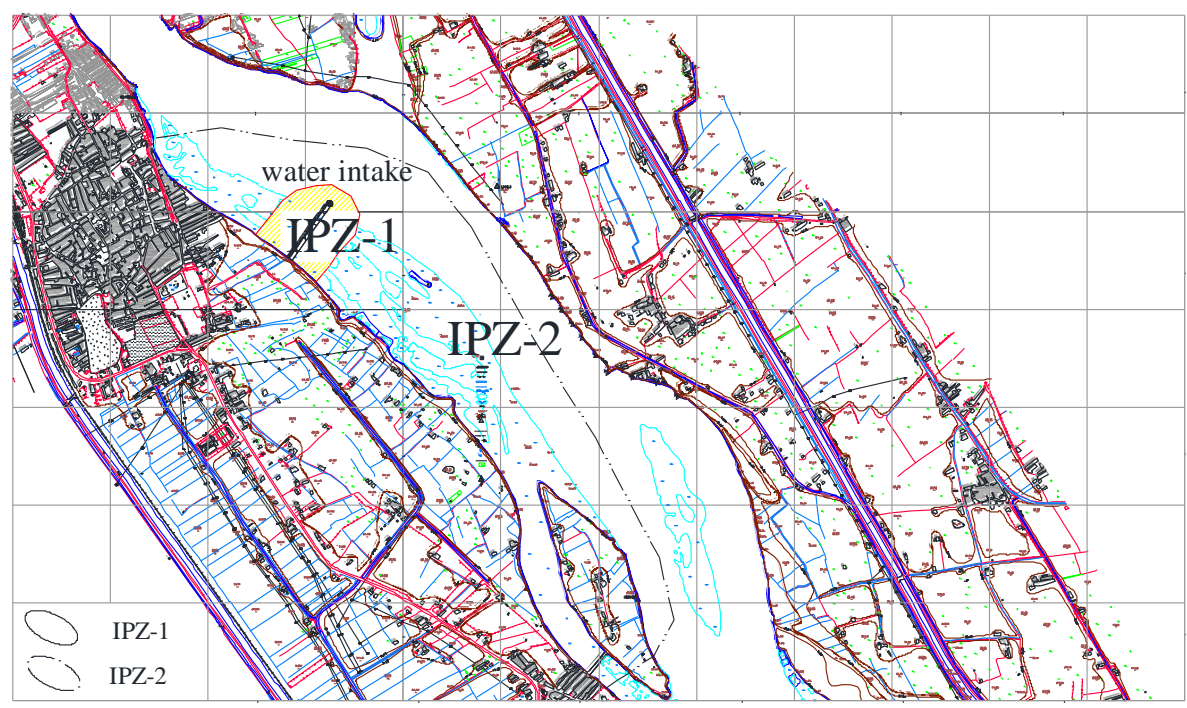

Figure (11): Abu Teg water intake station protection zones (for max flow condition)

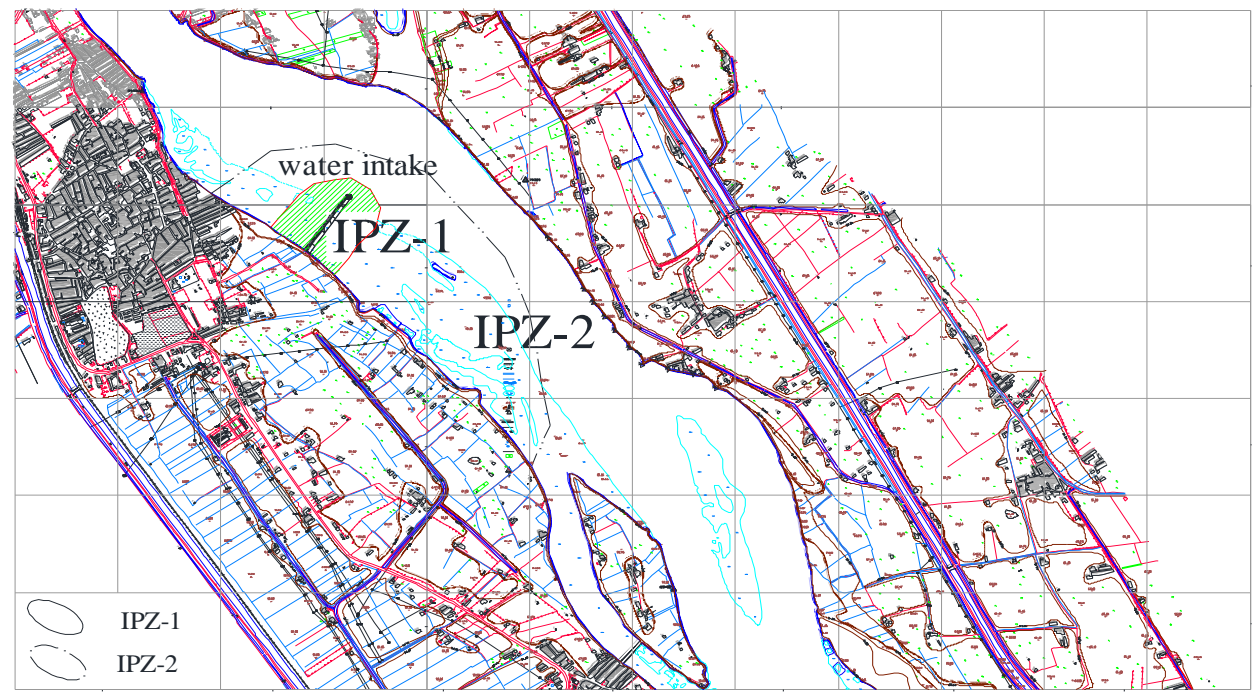

Figure(12): Abu Teg water intake station protection zones (for min flow condition) 


\section{REFERENCES}

W.F. Baird and Associates Coastal Engineers Limited. (2010): Ottawa River Surface Water Intake Protection Zone Study", Assessment Ottawa River report, Ontario Ministry of the Environment.

Devries, J.J., M. and Hartman, W. (1988): "Sediment modeling for the Sacramento River Diversion to the Peripheral Canal". Proceedings of the International Symposium, 9 th - 11 th August, California, 463 - 474.

Dereje, H. (2003): "River Intake Structures and Conveyance Systems", Workshop paper presented at the NBCBN-RE workshop held in Addis Ababa, Ethiopia

Erbisti, P.C.F. (2005): "Design of Hydraulic Gate", Sediment Transport Similitude for Scaled Physical Hydraulic Modelling, 33 rd IAHR Congress, 9 th - 14 th August, Vancouver, British Columbia, Canada

Moussa, A. M.A., (2010): Solving the problem of sedimentation at water intake of Rowd El-Farag pump station using 2D model. Ain Shams Engineering Journal, 1: 103-114.

Nakato, T. And Ogden, F.L. (1998). "Sediment Control at Water Intakes along Sand-Bed Rivers", Journal of Hydraulic Engineering, 124: 589 - 596.

NRI, (2005): Nile research institute "drinking water station Abu Teg (Assuit)", NRI report ,National Water research Center, ElQanater, Egypt.

NRI, (2009): Nile Research Institute "Study the problem of sedimentation at Abu Teg water station intake", NRI report, National Water research Center, Egypt.

Ontario Ministry of the Environment. (2009): Technical Rules: Assessment Report, Clean Water Act, 2006.Dated November 16, 2009.

Pirestani, M.R., Vosoghifar, H.R., and Jazayeri, P., (2011): Evaluation of Optimum Performance of Lateral Intakes. World Academy of Science, Engineering and Technology, 80: 369-3 


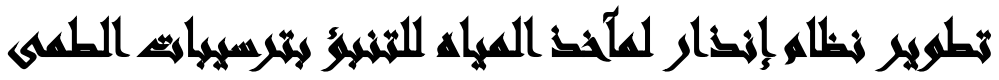

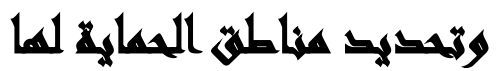

[

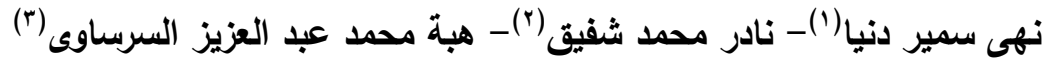

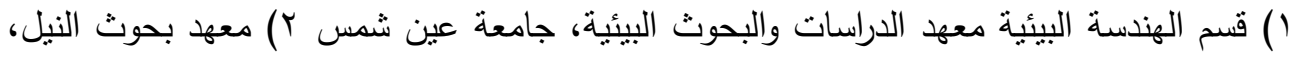
المركز القومي لبحوث المياه ץ) معهد بحوث النيل، المركز القومى لبحوث المئ المياه

\section{(المستخلس}

تستخدم ماخذ المباه على الانهار فى كثير من الاستخدمات مثل فى محطات مثات توليد الطاقة

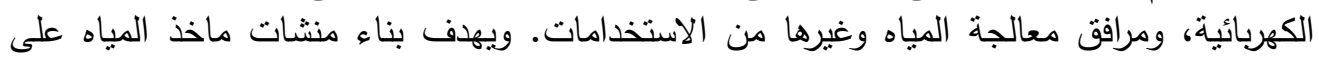
النهر الى تحويل كمية معينة من المياه من النهر لعدة من من الإنهاهية الاستخدامات. معظم المشاكل البيائية

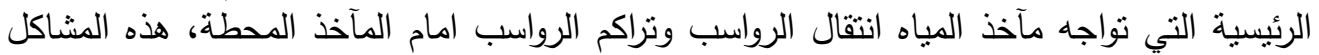

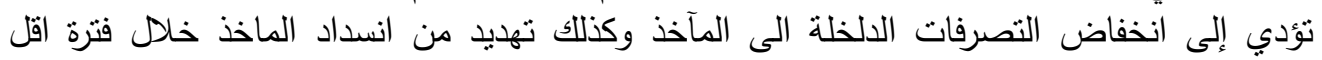
المناسيب و من المشاكل الاخرى التى تواجه الماخذ هى ان المياه المستمدة من الأنهار للمآخذ عرضة بطبيعتها للتلوث. الهدف الرئيسى من هذه الدراسة هو تطوير نظام الإنذار المبكر لتقدير المعدل السنوي للترسيب

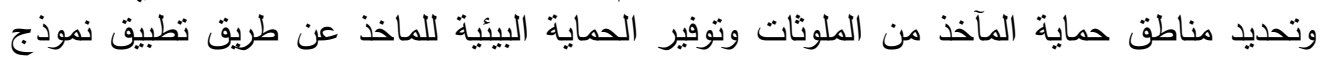

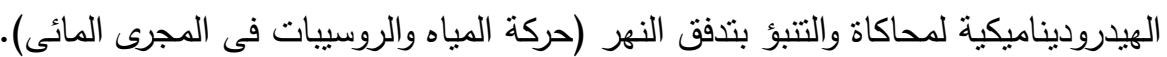

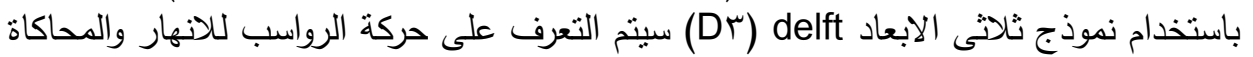

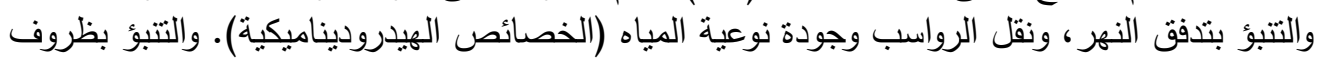

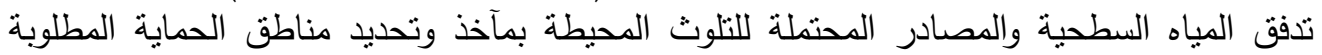

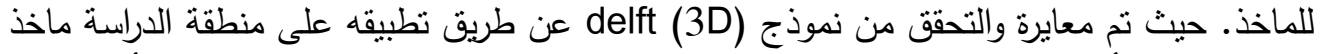

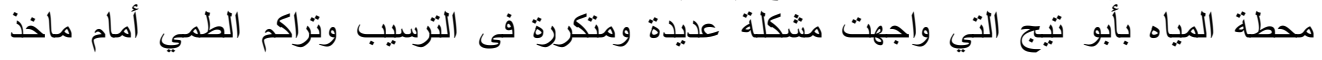

ومما سبق نسنتتج من هذه الدراسة إلى أن المعدل السنوي للترسيب الرواسب امام ماخذ محطة المحطة.

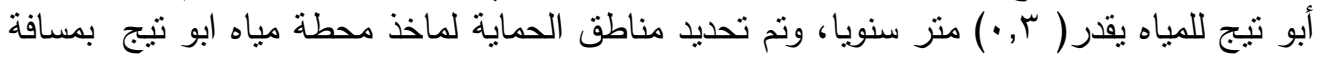

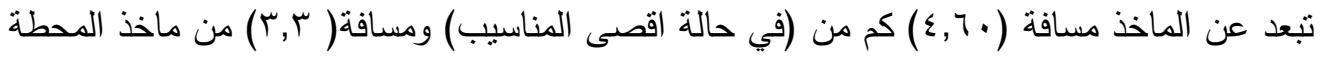

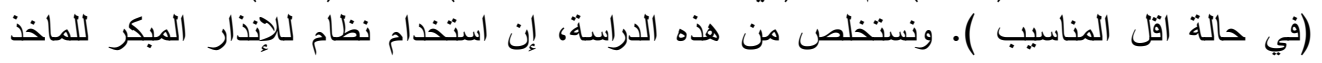

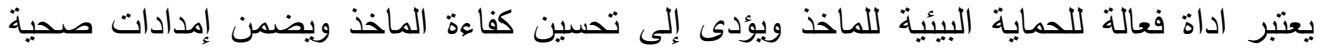

